\title{
PENGOPERASIAN CARGO CONTROL ROOM UNTUK KELANCARAN PROSES BONGKAR MUAT PADA KAPAL MT. KETALING
}

\author{
Samsul Huda ${ }^{a}$, Andri Yulianto ${ }^{\mathrm{b}}$ dan Taufik Qur Romadhon ${ }^{\mathrm{c}}$ \\ a dan b Dosen Program Studi Nautika PIP Semarang \\ ${ }^{c}$ Taruna (NIT.48114003.N) Program Studi Nautika PIP Semarang
}

\begin{abstract}
ABSTRAK
Cargo control room mempunyai peranan yang sangat penting terhadap kelancaran proses bongkar muat di kapal tanker, maka apabila dalam pengoperasian cargo control room tidak berjalan dengan baik dan benar, maka proses bongkar muat akan tehambat dan hal ini dapat mengakibatkan kerugian bagi perusahaan. Dalam penelitian ini diambil beberapa masalah mengenai bagaimana cara pengoperasian cargo control room yang baik agar proses bongkar muat dapat berjalan dengan lancar dan kesalahan-kesalahan apa saja yang menjadi hambatan dalam pengoperasian cargo control room.

Dalam menulis penelitian ini penulis menggunakan penelitian melalui pendekatan kualitatif karena akan menyajikan data-data yang diperoleh secara deskriptif atau membuat gambaran mengenai situasi atau kejadian dan lebih banyak melakukan observasi dan wawancara secara langsung terhadap objek.

Hasil penelitian yang dilakukan penulis selama praktek di kapal MT. Ketaling, pengoperasian cargo control room di MT. Ketaling masih belum berjalan dengan baik karena perwira jaga masih sering melakukan kesalahan dan sering mengalami kendalakendala dalam pengoperasian cargo control room, perwira jaga tidak mengetahui line-line pipa muatan yang harus dibuka saat pembongkaran, perwira jaga tidak menyiapkan alat komunikasi dan kurangnya pengawasan selama proses bongkar muat di cargo control room. Pembahasan dalam penelitian ini adalah pengoperasian cargo control room ada tiga tahap yaitu persiapan, pengawasan dan pelaksanaan. Kendala yang menghambat antara lain Kebocoran pipa, kerusakan pompa, alat komunikasi, salah komunikasi, kurang pengawasan, perwira mengandalkan juru pompa, serah terima jaga kurang baik. Untuk mengatasi kendala tersebut dengan cara merawat pompa, alat komunikasi, berkomunikasi dengan baik, pengawasan rutin, memberi pelatihan dan melakukan serah terima dengan baik.
\end{abstract}

Kata kunci: cargo control room, pompa-pompa, bongkar muat, kapal tanker, metode kualitatif

\section{PENDAHULUAN}

Pengangkutan merupakan kegiatan yang sangat penting dalam kehidupan masyarakat dan karena kondisi Indonesia maupun negara-negara di dunia ini terpisah oleh lautan, sungai dan danau maka pengangkutan tersebut dapat di lakukan melalui darat, laut maupun udara. Kapal merupakan sarana angkutan laut untuk melakukan perpindahan barang dari satu daerah ke daerah lain atau dari satu pelabuhan ke pelabuhan lain dengan cepat, aman dan tepat waktu baik dalam negeri maupun luar negeri. Seiring dengan perkembangan zaman di mana tingkat pengetahuan manusia semakin tinggi dan tingkat kebutuhan manusia akan barang semakin besar, maka bentuk dan daya muat kapal semakin canggih dan perkembangannya semakin besar pula.

Kapal dapat dibedakan menjadi berbagai macam jenis sesuai dengan muatan yang akan diangkut oleh kapal tersebut dan salah satunya adalah kapal tanker (kapal minyak). Sebuah kapal tanker dapat memuat 
bermacam-macam jenis minyak, mulai dari minyak mentah sampai minyak olahan atau jadi sesuai dengan jenis muatannya, tanker dapat dibedakan dalam 3 (tiga) kategori yaitu :

1. Crude Carriers yaitu kapal tanker untuk pengangkutan minyak mentah.

2. Black Oil Product Carriers yaitu kapal tanker yang mengutamakan pengangkutan minyak hitam seperti MDF (Marine Diesel FuelOil) dan sejenisnya.

3. Light Oil Product Carriers yaitu yang sering mengangkut minyak petroleum bersih seperti kerosene, gas oil dan sejenisnya.

Tiap-tiap jenis kapal masih dibagi berdasarkan muatan yang diangkut. Berdasarkan pengalaman selama praktek dan judul penelitian yang penulis ambil, maka penulis akan lebih memprioritaskan pada kapal tanker yang mengangkut minyak hitam khususnya MFO (Marine Fuel Oil).

Sedangkan sarana transportasi yang dibutuhkan untuk mengangkut muatan MFO ini adalah jenis kapal tanker khusus yang memuat minyak hitam. Untuk itu dalam proses bongkar muat harus berjalan dengan baik dan salah satu faktor keberhasilan dalam proses bongkar muat ini yaitu pengoperasian cargo control dengan baik dan benar. Tetapi sebelum kita membahas tentang pengoperasian cargo control room di kapal tanker ada baiknya kita mengetahui terlebih dahulu kegunaan dari cargo control room. Di kapal tanker tempat alat-alat untuk cargo control ini disebut cargo control room. Cargo control room di kapal digunakan untuk menyiapkan jalur-jalur yang akan dilalui oleh muatan minyakkarena kran-kran pipa hidrolik, untuk mengoperasikan pompa-pompa yang akan digunakan dalam pelaksanaan proses bongkar muat, untuk memonitor seberapa banyak muatan yang sudah dimuat atau dibongkar karena di cargo control room terdapat panel-panel untuk melihat tinggi muatan yang ada di tangki. Di dalam cargo control room bisa juga dilihat kemiringan dan stabilitas kapal karena di dalam cargo control room ada alat yang namanya clino meters (alat untuk melihat kemiringan kapal).

Agar proses bongkar muat berjalan dengan baik maka salah satu faktor keberhasilan dalam proses bongkar muat ini yaitu pengoperasian cargo controlroom dengan baik dan benar apabila pengoperasiannya tidak bisa berjalan dengan baik dan benar maka proses bongkar muat akan terhambat sehingga kapal akan berakibat sanksi delay. Kejadian ini pernah penulis alami pada waktu pembongkaran MFO di pelabuhan tanker atau jetty pertamina Pontianak. Karena kesalahan dalam pengoperasian cargo control room sehingga pompa muatan tidak bisa menghisap dengan baik, akibatnya proses pembongkaran ini berjalan lama dan tidak sesuai dengan jadwal yang ditetapkan. Hal ini sangat merugikan perusahaan khususnya tempat taruna melaksanakan praktek yaitu di PT. Pertamina.

Berdasarkan

permasalahanpermasalahan yang sering terjadi di kapal inilah, maka dalam penyusunan laporan penelitian ini penulis mengambil judul tentang "Pengoperasian Cargo Control Room Untuk Kelancaran Proses Bongkar Muat Pada Kapal MT. Ketaling”.

Dalam pengoperasian cargo control room banyak hambatan-hambatan yang di temui. Berdasarkan pengalaman serta pengamatan yang telah dilakukan oleh penulis selama melaksanakan praktek di MT. Ketaling, dengan ini maka penulis memberikan perumusan masalah dalam penelitian ini.

1. Bagaimanakah cara pengoperasian cargo control room yang baik agar proses bongkar muat dapat berjalan dengan lancar?

2. Kesalahan-kesalahan apa sajakah yang dapat memperlambat proses pengoperasian cargo control room?

Begitu banyak dan luasnya permasalahan yang timbul pada saat pengoperasian kapal tanker muatan minyak hitam, maka penulis membatasi permasalahan hanya pada saat kapal tanker 
melaksanakan proses bongkar muat terutama dalam pengoperasian cargo control roomkarena kegiatan ini sangat vital dalam proses bongkar muat tersebut. Adanya keterbatasan waktu, keterbatasan pengetahuan dan kesempatan penulis, maka dalam penulisan penelitian ini penulis membuat batasan masalah atau ruang lingkup.

1. Pembahasan hanya mencakup masalah pengoperasian cargo control room di MT. Ketaling.

2. Hanya mencakup masalah-masalah yang sering terjadi di kapal MT. Ketaling selama penulis melakukan praktek laut di kapal tersebut dari tanggal 09 Agustus 2013 sampai tanggal 10 Agustus 2014.

\section{KAJIAN PUSTAKA}

\section{A. Kajian pustaka}

1. Pengertian operasional

Menurut Chaer

operasional adalah suatu serangkaian proses dan cara mengoperasikan suatu alat ataupun sistem secara baik. Disini dapat diambil suatu kesimpulan bahwasannya suatu proses pengoperasian adalah proses perbuatan atau tindakan mempergunakan suatu alat secara baik dan prosedural untuk mendapatkan suatu hasil yang diinginkan.

2. Pengertian cargo control room

Menurut Baptist (2005:18), cargo control room (CCR) merupakan suatu tempat untuk mengoperasikan bongkar muat muatan pada kapal tanker. Jadi proses bongkar muat di dalam tangki dikendalikan di ruangan ini. Ccargo control room sebaiknya terletak di atas kamar pompa agar dapat melihat ke atas tangki muatan dengan jelas, selain itu cargo control room juga harus memiliki ruangan yang cukup besar untuk tempat alat kontrol dan peralatan-peralatannya. Cargo control room di MT. ketaling berada di ruang akomodasi di deck pertama bagian depan. Dari dalam cargo control room tersebut, kita bisa melihat kondisi di luar di atas tangki-tangki muatan dan juga aktifitas para crew di atas deck. Kelancaran proses bongkar muat di kapal tanker khususnya di MT. Ketaling sangat bergantung pada pengoperasian cargo control room.

3. Prinsip bongkar muat

Menurut Arso Martopo (2001:2) Proses penanganan dan pengoperasian muatan didasarkan pada prinsip-prinsip pemuatan :

a. Melindungi kapal (to protect the ship).

Maksudnya adalah untuk menjaga agar kapal tetap selamat selama kegiatan bongkar muat maupun dalam pelayaran agar layak laut dengan menciptakan suatu keadaan perimbangan muatan kapal.

b. Melindungi muatan (to protect the cargo).

Dalam perundang-undangan internasional dinyatakan bahwa perusahaan pelayaran atau pihak kapal bertanggung jawab atas keselamatan dan keutuhan muatan, muatan yang diterima di atas kapal secara kualitas dan kuantitas harus sampai ditempat tujuan dengan selamat dan utuh, oleh karenannya pada waktu memuat, di dalam perjalanaan maupun pada saat membongkar haruslah diambil tindakan untuk mencegah kerusakan muatan tersebut.

c. Keselamatan kerja buruh dan anak buah kapal (safety of crew and long shore man).

Untuk menjamin keselamatan kerja dan keselamatan kerja buruhburuh serta anak buah kapal, maka dalam operasi bongkar muat kapal perlu diperhatikan beberapa hal, antara lain :

1). Tugas-tugas anak buah kapal selama proses pemuatan dan pembongkaran.

2). Keamanan pada waktu pemuatan dan pembongkaran muatan 
d. Kelestarian (environment Protect).

lingkungan

Dalam melaksanakan kegiatan bongkar muat perlu diperhatikan masalah kelestarian lingkungan. Sedapat mungkin dihindarkan pencemaran atau kerusakan lingkungan sekitar yang diakibatkan oleh kegiatan tersebut.

e. Memuat / membongkar muatan secara tepat dan sistematis (to obtain rapid and systematic loading and discharging).

Maksudnya adalah melaksanakan bongkar muat diusahakan agar tidak memakan waktu banyak, maka sebelum kapal tiba di pelabuhan pertama (first port) di suatu negara, harus sudah tersedia rencana pemuatan dan pembongkaran (stowage plan).

f. Memenuhi ruang muat (to obtain maximal use of available cubic of the ship).

Untuk mendapatkan keuntungan yang maksimal, maka tiap-tiap perusahaan perkapalan menginginkan kapal-kapalnya membawa muatan secara maksimal pula, dimana kapal dimuati penuh di seluruh tanki.

\section{METODE PENELITIAN}

\section{A. Metode Penelitian}

Metode penelitian yang digunakan oleh penulis dalam penyampaian masalah adalah metode kualitatif, untuk menggambarkan dan menguraikan objek yang diteliti. Menurut Lexy J. Moleong, M.A (2005:98), mendefinisikan metode kualitatif adalah pengamatan, wawancara, atau penelaahan dokumen. Metode kualitatif ini digunakan karena beberapa pertimbangan :

1. Menyesuaikan metode kualitatif lebih mudah apabila berhadapan dengan kenyataan jamak.
2. Metode ini menyajikan secara langsung hakikat hubungan antara peneliti dan responden.

3. Metode ini lebih peka dan lebih dapat menyesuaikan diri dengan banyak penajaman pengaruh bersama terhadap pola-pola nilai yang dihadapi.

Oleh karena itu di dalam pembahasan nanti penulis berusaha memaparkan hasil dari semua studi dan penelitian mengenai suatu objek yang diperoleh, baik hal-hal yang bersifat teori juga memuat hal-hal yang bersifat praktis, dalam artian bahwa selain ditulis dari beberapa literatur buku, juga bersumber dari objek-objek penelitian yang juga terdapat dalam buku. Penggunaan aspek observasi atau pengamatan sangat berperan dalam penulisan penelitian ini.

\section{B. Waktu dan lokasi Penelitian}

Pada pelaksanaan proses penelitian ini penulis melakukan praktek lapangan yang penulis lakukan selama bulan Agustus 2013 sampai bulan Agustus 2014 di kapal MT. Ketaling, yang merupakan salah satu kapal milik PT. Pertamina yang berkantor di Jl. Yossudarso no 32-34 Tanjung Priok Jakarta utara. Kapal ini merupakan jenis kapal tanker yang dibuat untuk mengangkut jenis muatan minyak mentah, tapi selama penulis praktek di kapal tersebut muatannya diganti dengan minyak hitam yaitu M.F.O. Proses bongkar muat di kapal MT. Ketaling dioperasikan di dalam cargo control room dengan system hidrolik (dongkrak).

Kapal MT. Ketaling memiliki 26 awak yang terdiri dari 4 perwira deck, 4 perwira mesin, 1 electrician, 1 pump man, 1 bosun, 3 juru mudi, 3 kelasi, 1 mandor mesin, 3 juru mesin, 1 koki, 1 pelayan, 2 kadet deck dan 1 kadet mesin. Dari ke 26 awak kapal tersebut, kesemuanya berasal dari Indonesia.

\section{Sumber Data}

Data yang digunakan dan dikumpulin dalam penyusunan penelitian ini adalah data yang berupa keterangan dan informasi yang diperoleh melalui observasi maupun studi pustaka dari sumber-sumber tersebut diperolah dari data sebagai berikut : 


\section{Data Primer}

Data primer merupakan objek yang meberikan informasi dan data secara langsung sebagai hasil pengumpulan dan disiarkan sifatnya benar-benar orisinil. Disebut orisinil karena memberikan informasi yang tidak pernah dikumpulkan sebelumnya. Jadi dapat disimpulkan bahwa data primer merupakan suatu obyek data orisinil yang berupa data mentah dimana data tersebut tidak pernah dikumpulkan sebelumnya. Data ini dikumpulkan oleh peneliti secara langsung pada obyek penelitian dengan cara melakukan pengamatan pelaksanaan muat dan bongkar di MT. Ketaling. Dalam hal ini data yang diambil dengan cara pengamatan dan wawancara dengan orang-orang yang terlibat secara langsung pada materi.

2. Data Sekunder

Data sekunder merupakan data yang diperoleh penulis sebagai data yang digunakan untuk mendukung atau melengkapi data yang sudah penulis dapatkan secara langsung. Data tersebut penulis dapatkan melalui catatan-catatan log book (catatan kapal), catatan perwira kapal atau mungkin hasil survei yang belum diolah dan dianalisa lanjutan dapat menghasilkan sesuatu yang amat berguna, dan juga diperoleh melalui buku-buku yang berkaitan, hasil seminar, dan arsip peraturan nasional maupun internasional yang menunjang penelitian.

\section{Metode Pengumpulan Data}

Metode pengumpulan data ialah teknik atau cara-cara yang dapat digunakan oleh peneliti untuk mengumpulkan data.Pengumpulan data dimaksudkan untuk memperoleh bahan-bahan yang relevan, akurat, dan nyata.Untuk memperoleh datadata tersebut, antara lain wawancara, observasi, dan kepustakaan. Masing-masing data memiliki kelebihan dan kekurangan sendiri-sendiri. Karena itu lebih baik mempergunakan suatu pengumpulan data lebih dari satu, sehingga semua dapat saling melengkapi satu sama lain untuk menuju kesempurnaan penelitian ini. Di dalam penelitian ini penulis menggunakan beberapa teknik pengumpulan data :

\section{Riset Lapangan}

Teknik pengumpulan data dengan mengadakan observasi langsung ke objek penelitian yaitu dengan melaksanakan praktek laut selama 12 bulan 1 hari di atas kapal MT. Ketaling, sehingga datadata yang dikumpulkan sesuai dengan kenyataan yang ada pada saat penelitian berlangsung.

Dengan demikian akan didapatkan data yang diyakini kebenarannya, observasi yang penulis lakukan pada penelitian ini dilakukan dengan 2 (dua) cara :

a. Metode interview

Mendefinisikan metode interview adalah percakapan dengan maksud tertentu, percakapan itu dilakukan oleh dua pihak yaitu pewawancara yang mengajukan pertanyaan dan yang diwawancarai yang memberikan jawaban atas pertanyaan itu. Metode tersebut penulis lakukan untuk memperoleh data yatu dengan bertanya langsung kepada perwira dan crew di atas kapal tentang pengoperasian cargo control room untuk kelancaran proses bongkar muat di kapal MT. Ketaling.

\section{b. Metode observasi}

Metode observasi yaitu melakukan pengamatan secara langsung ke objek penelitian untuk melihat dari dekat kegiatan yang dilakukan. Apabila objek penelitian bersifat perilaku dan tindakan manusia, fenomena alam (kejadian-kejadian yang ada di alam sekitar), proses kerja, dan penggunaan responden kecil. Teknik observasi digunakan dengan maksud untuk mendapatkan atau mengumpulkan data secara langsung selama melaksanakan praktek laut selama pengoperasian cargo control room di kapal, di mana penulis mengikuti dan terjun langsung pada kegiatan 
pengoperasian cargo control room sehingga setiap kejadian yang ada dapat diketahui secara langsung oleh penulis.

2. Studi dokumenter

Teknik dokumenter adalah cara mengumpulkan data melalui peninggalan tertulis, seperti arsip-arsip dan termasuk juga buku-buku tentang pendapat, teori, dalil atau hukum dan lain-lain yang berhubungan dengan masalah penelitian. Metode dokumentasi ini sebagai pelengkap dari penelitian suatu penulisan, metode ini penulis laksanakan dengan cara melihat semua dokumendokumen yang berhubungan dengan masalah yang dibahas dalam penelitian ini, baik dokumen dari muatan yang telah dibawa oleh kapal ataupun dokumen tentang data-data kapal yang telah tersedia di kapal.

3. Studi pustaka

Menurut Nasution tinjauan pustaka adalah cara mencari data suatu penelitian yang memerlukan bahan yang bersumber dari perpustakaan. Studi kepustakaan merupakan penelitian yangdilakukan di dalam ruang perpustakaan untuk menghimpun dan menganalisis data yang bersumber dari perpustakaan, yang dapat dijadikan sumber rujukan untuk menyusun suatu laporan ilmiah.Buku-buku yang penulis baca sebagai bahan referensi yang mendukung penelitian ini adalah buku-buku yang terdapat di perpustakaan PIP (Politeknik Ilmu Pelayaran) Semarang, serta sumber referensi lain dan buku dari kapal, kegiatan ini ditujukan sebagai dokumen catatan peristiwa yang sudah berlalu.

\section{E. Analisa Data}

Menurut Nasution (2008:126), analisa data adalah menyususn data agar dapat ditafsirkan dan diketahui maknanya. Analis dikerjakan sejak peneliti mengumpulkan data dan dilakukan secara intensif setelah pengumpulan data selesai. Menurut Moleong (2004:248), analisa data adalah upaya yang dilakukan dengan jalan bekerja dengan data, mengorganisasikan data, memilah-milahnya menjadi satuan yang dapat dikelola, mensintesiskannya, mencari dan menemukan pola, menemukan apa yang penting dan apa yang dipelajari, dan memutuskan apa yang dapat diceritakan kepada orang lain.

Dalam penulisan penelitian ini penulis menggunakan metode analisa data, dengan cara menganalisa data-data yang diperoleh dari hasil penelitian. Selanjutnya penulis membuat penyajian data, penyajian data ini merupakan penjabaran dari data-data yang diperoleh dari hasil penelitian sebelumnya yang telah disusun dengan urut sehingga diperoleh penyajian data yang mudah dipahami dan dimengerti oleh pembaca.Selain isi dari penulisan penelitian ini dapat dipahami, dimengerti sekaligus juga dapat menjadikan suatu pengetahuan atau petunjuk yang mungkin dapat diterapkan di atas kapal nantinya. Dalam penulisan penelitian ini penulis menggunakan tiga macam metode analisa data :

\section{Reduksi data}

Reduksi data pada mulanya diidentifikasikan satuan yaitu bagian terkecil yang ditemukan dalam data yang memiliki makna bila dikaitkan dengan fokus dan masalah penelitian. Dari uraian di atas dapat disimpulkan bahwa reduksi dapat didefinisikan sebagai proses pemilihan, pemusatan perhatian pada penyerderhanaan, pengabstrakan dan transformasi data kasar yang muncul dari catatan tertulis di lapangan.

2. Penyajian data

Penyajian data adalah data populasi atau sample yang sudah terkumpul dengan baik, apabila digunakan untuk keperluan informasi, laporan atau analisis lanjutan hendaknya diatur, disusun dan disajikan dalam bentuk yang jelas, rapi 
serta komunitatif dengan cara menampilkan atau menyajikan data yang lebih menarik publik.

3. Menarik kesimpulan

Menarik kesimpulan merupakan kemampuan seorang peneliti dalam menyimpulkan berbagai temuan data yang diperoleh selama proses penelitian berlangsung.

\section{F. Prosedur Penelitian}

Menurut Lexy J. Moleong (2000:127148) dalam buku Metodologi Penelitian Kualitatif, tahap-tahap dari prosedur penelitian :

1. Tahap Pra Lapangan yang terdiri dari:

a. Menyusun rancangan penelitian

b. Memilih lapangan penelitian

c. Mengurus perizinan

d. Menjajaki dan menilai keadaan lapangan

e. Memilih dan memanfaatkan informan

f. Persoalan etika penelitian

2. Tahap pekerjaan lapangan yang terdiri dari:

a. Memahami latar penelitian dan persiapan diri

b. Memasuki lapangan

c. Berperan serta sambil mengumpulkan data

3. Tahap analisa data yang terdiri dari :

a. Konsep dasar analisa

b. Menentukan tama dan merumuskan masalah

c. Menganalisa berdasarkan hipotesis

Dari data-data yang diperoleh dari penelitian yang telah dilakukan sebelumnya, penulis menganalisa data tersebut sehingga dapat diperoleh mengenai pembahasan masalah-masalah yang didapat. Kemudian dari pembahasan masalah tersebut dapat diambil kesimpulannya dan penulis dapat memberikan saran-saran yang diperlukan.

Rancangam penelitian dalam penulisan penelitian ini memudahkan dalam hal-hal yang berhubungan dengan penelitian. Rancangan penelitian ini meliputi pengumpulan data, membahas data dan disimpulkan yang kemudian dituangkan dalam penelitian ini. Pada bagian ini mempersoalkan tahap-tahap penelitian yang nantinya memberikan gambaran tentang keseluruhan perencanaan, pelaksanaan pengumpulan data, analisa data, sampai pada penulisan laporan.

\section{DISKUSI}

\section{A. Pembahasan Hasil Penelitian}

1. Cara pengoperasian cargo control room yang baik agar proses bongkar muat dapat berjalan dengan lancer.

Dalam mengoperasikan cargo control room, perwira jaga harus mengetahui bagaimana prosedur dari pengoperasian cargo control room tersebut. Prosedur dari pengoperasian cargo control room.

a. Persiapan

1) Menyiapkan pompa

Untuk menyiapkan pompa hal pertama yang harus dilakukan adalah membuka valve secara manual yang berada di dalam kamar pompa / pumproom, setalah itu menyiapkan jalur-jalur muatan mana saja yang akan dilalui oleh muatan yang berada di cargo control room. Seorang perwira jaga juga harus mengetahui pompa mana yang akan digunakan kapal pada saat proses pembongkaran. Mualim 1 harus selalu memberitahu perwira jaga pompa mana yang akan dipakai dan seterusnya perwira jaga memberitahukan juru pompa dan kamar mesin sehingga tidak terjadi kesalahan informasi. Di kapal MT. Ketaling terdapat tiga buah pompa cargo, dua buah pompa ballast serta dua buah pompa stripping (pompa hisap). Pompa cargo dipakai untuk pembongkaran sedangkan pompa stripping (pompa hisap) dipakai untuk pengeringan tanki apabila pompa cargo sudah tidak bisa menghisap muatan lagi. 

2) Menyiapkan Jalur / Line-line pipa

Sebelum proses bongkar muat dimulai, perwira jaga harus memeriksa ulang terlebih dahulu jalur-jalur yang akan dilalui oleh muatan minyak, sehingga apabila masih terdapat kran-kran yang lupa untuk dibuka atau ditutup dapat diketahui dan dapat langsung diambil tindakan.

3) Menghidupkan semua control panel di cargo control room

Control panel ini adalah yang paling penting dalam pengoperasian cargo control room, karena dengan menghidupkan seluruh panel-panel kita akan dapat melihat berapa sisa muatan yang ada di masing-masing tangki melalui ullage guage (alat untuk memonitor ketinggian muatan di setiap tanki muatan), dan lain sebagainya tanpa harus ke deck untuk melihatnya.

4) Menyiapkan Handy Talky

Handy talky (radio jinjing) ini sangat berguna untuk berkomunikasi antara orang yang jaga di cargo control room dengan orang yang jaga muatan di atas deck tangki muatan. Apabila ada kebocoran pada pipa atau akan pengeringan muatan maka dapat diinformasikan melalui handy talky (radio jinjing).

b. Pelaksanaan

Setelah semua persiapan dilakukan maka pengoperasian cargo control room dapat dilakukan. Tetapi sebelum kita mengoperasikan cargo control room, kita terlebih dahulu harus melaksanakan prosedur proses pemuatan dan pembongkaran dengan baik dan benar :

1) Adapun prosedur proses pemuatan di kapal tanker.

a) Periksa ulang sambungan selang darat dengan manifold, dan valve-valve yang berhubungan dengan tangkitangki yang akan diisi muatan.

b) Apabila kapal sebelum memuat dalam keadaan miring yang tidak kita ketahui sebelumnya, sehingga apabila kapal memuat pada tangkitangki samping,

c) Perwira jaga harus memperhatikan petunjukpetunjuk yang diberikan mualim satu.

i. Jenis muatan yang dimuat pada setiap tangki.

ii. Ullage terakhir pada setiap tangki yaitu untuk mengetahui berapa sisa volume muatan yang masih berada di dalam tangki muatan.

iii. Perkiraan density dan temperature pada setiap jenis muatan.

iv. Jumlah muatan dalam barrel atau meter kubik untuk setiap jenis muatan serta trim kapal. Alat ini digunakan untuk mengetahui sudut kemiringan kapal dan trim pada saat itu. Sehingga perwira jaga dapat memonitor dan kapal pada saat proses bongkar muat berlangsung dan perwira jaga dapat tetap menjaga agar kapal tidak nungging atau terlalu mendongak dan kapal tidak terlalu miring kiri atau miring kanan pada saat proses bongkar muat berlangsung. Kejadian yang pernah dialami oleh MT. Ketaling yang 
berkaitan dengan alat

ini adalah pada saat pemuatan $M F O$ di pelabuhan Palembang. Karena kesalahan perwira jaga yang tidak memonitor alat ini pada saat pemuatan berlangsung sehingga kapal nungging. Apabila hal ini dibiarkan maka kapal tidak akan diijinkan untuk berlayar karena akan membahayakan kapal dan keselamatan crew.

d) Apabila satu tangki telah mendekati penuh dan akan memuati tangki lainnya, maka bukalah valve tangki yang akan dimuat sebelum menutup valve tangki yang selesai dimuati.

e) Keadaan tali-tali tros kapal harus selalu diperiksa setiap saat demi menjaga keselamatan waktu dalam pemuatan.

f) Tindakan selama proses pemuatan :

- Memeriksa sambungansambungan pipa darat dan manifold terhadap kemungkinan terjadinya kebocoran.

- Memeriksa posisi kapal setiap saat, demi menjaga keselamatan saat selama pemuatan.

- Menyiapkan segala alatalat pencegahan pencemaran (saw dust, oil dispersant, sapu, majun dan sebagainya).

- Lubang-lubang pembuangan air (scupper plug) harus ditutup rapat.
- Setiap kejadian yang dialami ditulis dalam $\log$ book muatan.

2) Sedangkan prosedur proses pembongkaran di kapal tanker adalah.

a) Pipa pembongkaran dari darat dipasang ke kapal, biasanya dihubungkan dengan common line, tergantung order dari mualim satu.

b) Harus ada komunikasi antara Rate pembongkaran per jam. Kita bisa menghitung rate secara manual maupun menggunakan komputer. Di MT pihak kapal dengan pihak darat melalui telpon, Handy talky, ataupun hubungan langsung.

c) Pembongkaran muatan dilakukan sesuai rencana yang telah dibuat oleh mualim satu dan perlu juga dicatat :

- Kapan selang darat mulai tersambung dengan manifold kapal.

- Kapan pembongkaran muatan di kapal dimulai.

- Situasi yang terjadi pada saat pembongkaran.

- Kapan pembongkaran mulai selesai.

d) Tindakan selama proses pembongkaran :

- Memeriksa sambungansambungan pipa darat dan manifold terhadap kemungkinan terjadinya kebocoran.

- Memeriksa posisi kapal setiap saat, demi menjaga keselamatan selama bongkar. Agar mengetahui kemiringan kapal kita bisa melihat Clinometer. Clinometer ini digunakan untuk mengetahui sudut kemiringan kapal. 

- Menyiapkan alat-alat pencegahan pencemaran (saw dust, oil dispersant, sapu, majun dan sebagainya).
- Lubang-lubang pembuangan air harus ditutup rapat.
- Setiap kejadian yang dialami ditulis dalam $\log$ book muatan.

c. Pengawasan

Pengawasan ini harus dilaksanakan secara terus menerus sampai selesainya proses bongkar muat. Setiap satu jam sekali perwira jaga harus mengambil rate muatan baik itu muat maupun bongkar. Juru pompa yang jaga harus selalu mengecek pompa ke kamar pompa, apakah pompa tersebut berjalan dengan baik. Dalam hal ini kerjasama diantara perwira jaga, juru pompa, cadet, juru mudi jaga dan kelasi jaga sangat diperlukan untuk menunjang keberhasilan pengoperasian cargo control room sehingga proses bongkar muat dapat berjalan dengan lancar.

2. Kesalahan-kesalahan yang dapat memperlambat proses pengoperasian cargo control room

Berdasarkan pengamatan peneliti di kapal MT. Ketaling ada beberapa kesalahan yang sering terjadi sehingga menghambat kelancaran pelaksanaan bongkar muat. Untuk itulah kesalahankesalahan yang ada itu harus dapat diatasi. Adapun kesalahan-kesalahan yang menghambat jalannya proses pengoperasian cargo control room di kapal MT. Ketaling.

a. Kebocoran pipa

Salah satu kesalahan yang dapat menghambat proses pengoperasian cargo control room adalah kebocoran pipa. Kebocoran pipa di kapal MT. Ketaling terjadi akibat tidak kuatnya reducer (sambungan pipa) menahan getaran yang diakibatkan oleh kecepatan muatan yang melalui pipa tersebut. Untuk mencengah terjadinya kebocoran pipa maka harus dilaksanakan pengecekan terlebih dahulu sebelum melaksanakan proses bongkar muat. Pengecekan dilakukan pada saat kapal akan memuat atau membongkar muatan.

b. Kerusakan pompa

Kerusakan pompa merupakan salah satu hal yang dapat menghambat proses pengoperasian cargo control room. Untuk mencegah terjadinya terjadinya kerusakan pompa maka perlu dilakukan :

1) Mengatur kecepatan pompa dengan baik agar dapat bekerja dengan baik karena pada saat mengoperasikan pompa dengan kecepatan tinggi akan membuat kondisi pompa cepat panas dan akan mati dengan sendirinya, begitu pula sebaliknya apabila pompa dioperasikan dengan kecepatan rendah maka pompa tersebut akan mati.

2) Perawatan secara berkala terhadap pompa-pompa muatan. Perawatan pompa-pompa muatan perlu dilakukan untuk menjaga kemampuan daya hisap pompa dan mencegah terjadinya kerusakan pada pompa-pompa muatan. Adapun perawatan terhadap pompa-pompa muatan meliputi:

a) Melakukan penggantian minyak pelumas baering setiap 600 jam kerja.

b) Cooler L.O digosok tiap 300 jam kerja.

c) Pembersihan saringan hisap setiap bulan.

c. Kerusakan alat komunikasi

Alat komunikasi sangat penting untuk digunakan pada saat pengopersian cargo control room. Alat komunikasi berperan penting dalam kelancaran pengoperasian cargo control room yaitu sebagai sarana komunikasi atara perwira di 
dalam cargo control room dengan juru mudi jaga. Kerusakan yang sering terjadi pada alat komunikasi adalah habisnya baterai alat komunikasi yang menyebabkan matinya alat komunikasi tersebut. Untuk mencegah terjadinya kerusakan pada alat komunikasi maka seharusnya disediakan baterai cadangan yang dapat digunakan bergantian apabila baterai utama habis.

d. Kurangnya pengawasan dari perwira jaga di dalam cargo control room

Kesalahan yang sering terjadi pada saat pengoperasian cargo control room adalah kurangnya pengawasan dari perwira jaga di dalam cargo control room seperti perwira jaga yang meninggalkan cargo control room selama jaga yang mengakibatkan tidak diketahuinya muatan sudah mencapai ullage (tinggi) yang sudah ditentukan oleh mualim 1. Untuk mencegah hal tersebut maka dalam pelaksanaan pengawasan proses bongkar muat perwira jaga harus melakukan pengawasan secara rutin. Apabila ada keperluan sebaiknya mencari pengganti sementara untuk melakukan pengawasan dengan catatan yang bersangkutan tidak terlalu lama meninggalkan tugasnya.

e. Perwira kapal yang belum bisa mengoperasikan cargo control room dengan baik

Kesalahan yang sering diakukan perwira kapal diatas kapal MT. Ketaling salah satunya adalah karena tidak bisa mengoperasikannya cargo control room oleh perwira di atas kapal yang disebabkan karena kurangnya keterampilan dan pengetahuan perwira kapal dalam mengoperasikan cargo control room. Untuk mencegah terjadinya kesalahan tersebut maka perlu dilakukan :

1) Melaksanakan Familiarisasi Tentang Pengoperasian Cargo Control Room.
Untuk anak buah atau crew kapal yang baru pertama kali bekerja di atas kapal tanker yang tentu banyak sekali mengalami kesulitan karena banyak sekali halhal yang belum diketahui terutama segala sesuatu yang menyangkut tata cara pemuatan dan pembongkaran juga pengoperasian peralatan bongkar muat termasuk cargo control room. Pelaksanaan familiarisasi diatas kapal dilakukan dengan cara sebagai berikut yaitu:

a) Pelaksanaan sosisalisasi Pelaksanaan sosialisasi dilakukan oleh Mualim Satu (Chief Officer) pada saat pergantian crew baru. Di dalam sosialisasi tersebut menerangkan tentang tugas dan tanggung jawab pada saat pengoperasian cargo control room pada awak kapal yang baru naik sehingga awak kapal tersebut dapat mengetahui dan paham akan tugas dan tanggung jawab pada saat mengoperasikan cargo control room.

b) Pelaksanaan Meeting Dalam pelaksanaan kegiatan ini adalah memberikan pengetahuan kepada seluruh awak kapal tentang bagaimana cara mengoperasikan cargo control room, sehingga seluruh awak kapal harus dapat mengoperasikannya sesuai dengan prosedur yang tepat. Dan juga mengadakan komunikasi langsung kepada seluruh awak kapal mengenai hambatanhambatan apa saja yang ditemui dalam pelaksanaannya dan sekaligus mencari solusi yang terbaik dari permasalahan tersebut.

2) Melaksanakan Diklat/ Training Secara Berkala

Untuk meningkatkan pemahaman para crew tentang 
pengoperasian Cargo Control

Room maka alternatif yang paling berhasil yaitu dengan diadakannya diklat / training tentang pengoperasian Cargo Control Room secara rutin di atas kapal.

f. Serah terima tugas jaga yang tidak baik

Kesalahan akibat serah terima tugas jaga yang tidak baik merupakan salah satu kesalahan yang menyebabkan terjadinya kesalahan saat mengoperasikan cargo control room. Kesalahan yang sering dilakukan saat serah terima tugas jaga yaitu tidak menyampaikan informasi secara lengkap tentang apa yang sedang dilakukan pada saat itu. Untuk mencegah terjadinya kesalahan pengoperasian cargo control room maka perwira jaga harus melaksanakan serah terima jaga dengan baik dengan melaporkan kondisi pekerjaan yang sedang dilakukan, memberikan informasi secara lengkap tentang alat-alat yang sedang dioperasikan dan order-order dari Nahkoda, mualim 1 dan pihak darat.

\section{KESIMPULAN}

\section{A. Kesimpulan}

Berdasarkan uraian-uraian yang terdapat pada bab-bab sebelumnya, tentang pengoperasian cargo control room untuk kelancaran proses bongkar muat di kapal MT. Ketaling, maka sebagai bagian akhir dari penelitian ini penulis memberikan simpulan dan saran yang berkaitan dengan masalah yang dibahas dalam penelitian ini.

1. Dari penelitian ini prosedur pengoperasian cargo control room di MT. Ketaling untuk menunjang kelancaran pelaksanaan bongkar muat perlu dilaksanakannya persiapanpersiapan seperti menyiapkan pompa, dan jalur perpipaan serta melaksanakan pengecekan terlebih dahulu terhadap kondisi pompa dan pipa.

2. Kesalahan-kesalahan yang sering terjadi dalam pengoperasian cargo control room antara lain kebocoran pipa, kerusakan pompa, kerusakan alat komunikasi, kurangnya pengawasan dari perwira jaga, masih ada perwira jaga yang belum bisa mengoperasikan cargo control room dan tidak melakukan serah terima jaga dengan baik.

\section{DAFTAR PUSTAKA}

Baptist, C. 2007. Tanker Handbook For Deck Officer. Glasgow, Scotland : Brown, Son And Ferguson Ltd

Arso, Martopo. 2001. Kapal dan Muatannya. Jakarta : Koperasi Karyawan BP3IP

Chaer. 2007. Metodologi Penelitian Pendidikan. Jakarta: Transmedia

Moleong J Lexy. 2005. Metodologi Penelitian Kualitatif. Jakarta: Remaja Rosdakarya

Nasution. 2008. Metode Research. Jakarta: Bumi Aksara

Moleong, Lexy J. 2004. Analisa Data. Bandung : Alfabeta 